Miriam Gigliotti, Laura Odasso

\title{
Becoming women: awareness of migration and double loyalty
}

\begin{abstract}
:
Based on two case studies of adolescent daughters of migrant and mixed families in Bavaria (Germany) and in Veneto (Italy), the paper aims to study how the daughters solve the conflicting interactions between the contents of the transmission and of the socialization. Focused mostly on gendered interactions and on a sense of belonging, the reflection investigates if and how structural elements (e.g.: family configuration, national context and migration trajectories of parents) impact on continuity and discontinuity in passing on values and other sets of information.

The observation of "status passages" and "socio-ecological transitions" in and between private and public spheres thanks to the analysis of life histories are suitable to grasp the specific effects of handing down and its interaction with the socialization over generations. This approach entails the articulation of "time" (namely the interplay between past and present) and "space" (namely the private and public spheres) allowing retracing the outline of the "generational work" that each family performs consciously and unconsciously. In different geographical and socio-cultural contexts as well as in different family patterns, parenting and adolescent dynamics reveal common features. By pointing out the restructuration that adolescence imposes in life courses, we show that it is the meaning given to the parental experience of migration that entails specific form of "loyalty" due to emotional and juridical (de)nationalized belonging, as well as to previous experiences of socialization and discrimination.

The originality of the reflection is connected to the patterns of the families compared. The authors widen the concept of migration classically employed in academia introducing the innovative concept of "migration of contact".
\end{abstract}

Keywords: migration - mixed family - adolescence - transmission - socialization - gender, denationalized belonging 


\section{Introduction}

„I'm not afraid to be what I am even if sometimes it is hard!” (Lia)

Family is the primary setting for socialization, as well as for intergenerational transmission. Interpersonal, verbal and non-verbal communications and symbolic acts pass on "something" of the parents (taste, know-how, knowledge) and safeguard family history and "myth" as symbolic heritage ${ }^{1}$ (Neuburger 2011, p. 32). Nevertheless, the simple "desire to pass something on" is not enough to assure the success of the process that "takes two to tango" (Varro 1992, p. 31). Considering the nuclear family, two subjects are involved: the parents (father and/or mother) propose "something" that they would want to pass on to their child and a child who either accepts or rather rejects more or less violently "what" is offered (Bertaux/Delcroix 2009, p. 92).

The set of significant information exchanged in the conjugal dyad's intimacy and handed down in the family intertwines with what is coming from the interactions with non-kin significant others (classmates, friends and workmates). Parents are supported or contradicted in their transmission by the subjects that act in the spaces of "secondary socialization", that is, peer groups at school, sports groups and other associations. These non-kin referents propose values that can be discordant or simply different from the ones received at home. Each family shows peculiar dynamics of transmission according to different kinds of capital (Bourdieu 1994) and the "subjective resources" (Delcroix 2013) developed along generations.

For migrant families, transmission is linked to new affiliations built over time through particular "status passages" (Glaser/Strauss 1971) that marked parents' identities and roles ${ }^{2}$ along a trajectory of reorganization. When they resettled, mothers and fathers had to redefine their personal identities and roles according to the new environment's "laws of functioning" (Elias 1991, p. 52). They learnt how to live in the presence or absence of supportive networks, to fulfill the "integration" (Sayad 1994) invitation or demand of institutions, as well as how to deal with transnational spaces. These passages impact on the content of the family's transmission. Even if mothers and fathers aim to reach a coherent transmission for preserving family memory as a solid frame, the outcome of their efforts are not just dependent on their effort. Confronted with prejudices, migrant families try to develop strategies to respond to everyday racism (Essed 1991) towards helping their children keep their self-esteem (Delcroix 2013). More than children of nonmigrants, these children are used to the everyday work of questioning values.

How does each parent's memory of migration impact on intergenerational transmissions? The meaning of migration changes over generations, impacting differently on children who have not chosen to migrate themselves. For the migrants, their migration has been a conscious decision for a courageous jump into the unknown, often in search of a better life if not for themselves, then at least for their children (Bertaux/Delcroix 2009). But for the children, their parents' migration is a fact of the past taken for granted about which they had no choice of their own and which they cannot change. Migration history is given, just as kin relations are given and not chosen. By contrast, non-kin relationships are chosen during pre-adolescence through affinity, thus, constructed, cultivated or dropped autonomously.

During adolescence, when youths need to respond to the biological, psychological and social "developmental tasks" (Claes 2003) entailed in establishing their 
own life, kin and non-kin interactions may originate discordances. How does the family's transmission and the external socialization influence the youths, especially when these process exercise "pressures" in opposite directions?

To answer these questions, we met the challenge to articulate the processes of transmission and socialization through the notion of belonging to a family, a group, or a nation by analyzing daughters' kin and non-kin ties in their transitions from adolescence to adulthood (Wall/Gouveia 2014, p. 353). Our aim is to observe if and how different national contexts and family configurations impact on the continuity and the discontinuity in transmission. Employing a gender perspective, we also ask if the parent's gender has any consequences on the modalities of transmission.

Firstly, we explain the methodology guiding our fieldwork and the analytic tools we employed. Then we will explain the cases we chose from our samples focusing on gender relations in and outside of the family sphere. We will conclude by broadening the classical notion of migration and, consequently, its impact on changes along generations.

\section{Grasping generational work}

In the framework of wider multi-sited ethnographies, we conducted in-depth and life story interviews ${ }^{3}$ with migrant and mixed (migrant/non-migrant) families. By crossing the analyses of each family member's biography with the others (Delcroix 1995), we deepened our analysis of kin relationships. Furthermore, we accessed a wider "fragment of socio-historical reality" (Bertaux 1997); by following the narrative paths of each family's member life history we touched the relevant status passages of these families. Thus, it was possible to perceive the "generational work" (Inowlocki 1993) accomplished. Such work is a reflexive ongoing negotiation (Schütze 1987). It refers to the individuals' effort of making sense on family changes throughout their life trajectory.

Having the possibility to observe everyday dynamics in families, we grasped their "socio-ecological transitions" (Apitzsch 1990, p. 115) ${ }^{4}$. These transitions are concrete frames of lives that unveil how contexts and institutions impact on individuals and, consequently, on their way to pass on and to socialize. Migration is explained as a specific ecological transition between individuals and contexts at large, but we presume that migration affects all the frames in which migrants and the individuals who are in contact with them, are involved over time. Concretely, migration impinges in all the spheres of intimate, private and public life and imposes ongoing elaborations of individuals' identities and roles, both in discourse and in practice.

In the following, we focus on the comparative cases of Sara, a German girl, and Lia, an Italian one. These adolescents have not directly experienced migration. Beyond the controversial outcomes of transmissions and socialisation, "instances of biographical work" (Inowlocki/Lutz 2000) in these two cases point out the impact of migration and social norms on intergenerational conflicts, alliances and solutions leading to adulthood. The case comparison connects the particular with the general, as "all single cases present something that is possible to generalize and as all family histories are not completely unique" (Bertaux-Wiame 1988, p. 9). 
Sara is the daughter of an Italian migrant family living in the state of Bavaria (Germany). Lia is the daughter of a Moroccan-Italian binational - and later on 'mixed' - couple ${ }^{5}$ (Odasso 2014) living in the region of Venetia (Italy). Our comparison based on these two different family configurations will come up with some counterintuitive results to reconsider the classical idea of migration and to widen the notion of belonging. If local negotiations are inevitable, gender and kin may be analyzed in a more universal perspective.

In more than one way, we were part of our research topics. We were two young Italian researchers based respectively in Strasbourg and Frankfurt, doing their $\mathrm{Ph}$.D. transnationally in cooperation with, respectively, Venice and Trento. Our "migration" for academic reasons inevitably impacted on the interactions with the interviewees. Italian belonging combined with migration experienced as women helped to create complicity with both the teenagers and the mothers we interviewed - „I think you can understand. I speak to you as a friend!” (Lia) - and with their mothers - „when you'll have a child you will understand!” (Anna). As Michael Burawoy (1998) stated, the characteristics of the researcher inevitably affect the fieldwork and the analysis of the results.

\section{Family history and kin ties}

Sara, twenty-seven years old at the time of the interview, was living in Munich with her parents: Ida, worker at Siemens, and Gianni, electrician. They had migrated with their respective families from Campania - the region of Naples - to Germany in the early 1960s during the "recruitment of migrant pioneers"6. They were respectively eight and eighteen years old at that time. They met when Ida was twenty-one and decided to get married quite rapidly. According to Sara's narrative, her parents succeeded in their migration project, working hard towards assuring financial security and a better future for her, their only daughter. Nowadays, they own their house and their economic position is stable. Social mobility is represented by the achievement of better economic, socio-cultural, and even linguistic and subjective capital ${ }^{7}$. „It's unbelievable, they achieved a position without speaking a word of German!" said the girl before turning the discussion towards their educational model and explaining through concrete examples how her parents have passed on a set of common values that have been shaped by the sacrifices they went through.

Nevertheless, Sara's disappointment about her mother's absences becomes obvious. Due to economic constraints, Ida had to work full-time, leaving Sara alone during her childhood. In the future, „under good economic conditions”, Sara hopes to be a housewife to spend time with her children. She criticizes her mother's decision to care for her grandmother. She sees the caring attitude towards elderly family members as rooted in the myth of the Italian family unity. Sara's narrative reshapes more classical gendered family's roles: women should take care of the new generation rather than the old one, while men should keep their breadwinners' role. She looks towards her future through a critical reflection of how her mother acted. This process of the "dialectic positioning concerning family values" (Apitzsch 1990) ${ }^{8}$ was first found in another biographical research on young Italian 
women and mostly concerns mother-daughter relations in term of role contestation. The daughter revisits everyday maternal practices until adopting a personal position. During adolescence, this process implies phases of agreement or disagreement with all the family members. Sara criticizes her mother's submission ${ }^{9}$ and incapacity to openly contradict Sara's father's educational model. Conversely, Sara argues with her father until reaching open disagreement and conflicts.

Her father has a significant role in Sara's positioning herself "inside" and "outside" her family. Attached to an Italian way of life, Gianni nonetheless criticizes his daughter's behavior: „You should not act like other Italians do in Germany! Separate between private and professional life! Outside, don't speak too much!" Gianni's attitude is the consequence of his own migration experience to Germany. Italians were structurally, socially, and economically marginalized, through disqualified jobs, living in shack houses in suburban areas, and the impossibility to vote. They were considered as temporary workers and "second class citizens" in Germany ${ }^{10}$ (Negrini 2001, pp. 60-62). In Italy, they were considered to be "marginal citizens" for living outside the country.

Among "migrants" in Italy, similar family dynamics can been observed. Lia, eighteen years old at the time of the interview, was attending a science oriented high school and living with her parents and younger sisters, Salima and Naima11, in a village near Treviso in Veneto - North-East of Italy -, where she was born and grew up. Her parents, Amin, a factory worker, and Anna, secretary in a public office, had met a few months after Amin's arrival in Italy from Morocco in $1989^{12}$. They went out together and starting to cohabit when Anna became pregnant. Her family ${ }^{13}$ did not accept her relation with a Muslim foreigner for a long time and she was disqualified by her own society for her choice in love. After ten years together, in 2001, Anna and Amin married in a civil court and in 2002 religiously. Since Amin is Muslim and Anna is Christian ${ }^{14}$, they celebrated a "mixed religion" marriage.

Gianni and Amin's migrant conditions share a lot of commonalities. They were both for some time semi-citizens and, as men who were migrant workers from the South, they suffered from violent stigmatization. Amin and his family lived in an economically prosperous region. The remarkable economic boom of the 1990s was accompanied by an increased popularity of right wing parties (e.g.: Lega Nord ${ }^{15}$ ) and of a public expression of racism ${ }^{16}$. Since their arrival in 1980, Moroccans in Italy report discrimination very similar to what Italians experienced in Germany. The framework of socio-institutional stigmatization experienced directly or indirectly by their families is an element common to Lia's and Sara's biographical experiences.

In this social environment, Lia's father imposed strict rules, controlling his daughter's friends and her evenings spent outside, exactly as his own father who „wanted to decide about everything” used to do ${ }^{17}$. On the opposite, Anna - as Sara's mother - affirms that she does not want to reproduce her parents' behavior, particularly her father's behavior that caused a rupture in the family that only Lia's birth and Anna's mother's mediation were able to repair. Anna's model of education is highly devoted to safeguard family unity: „It's time for her to make her own decisions, as I have done! But try to put yourself in her shoes! I have a daughter who tells me that she is looking forward to leaving home! It is hard to mediate this! I agree about giving her limits, but she has the right to have certain friendships!"

As in Sara's case, mother and daughter protect each other while appealing to respectively their husband and father. The men propose "discursive rules" for be- 
havior but in practice delegate the implementation of decisions to their wives. Hence, Anna's behavior varies between negotiation and incapacity to openly question her husband's role, as Lia's observations illustrate: „When I ask my father, he says 'go to your mum!' I go to my mum; she says 'go to your father!' So I directly avoid certain activities without asking, as I already know"

Similar to her parents ${ }^{18}$, Lia is socially active in what she herself defines as "protected" environments. Her father approves that she is involved with scouts and church groups. Family peace both in the conjugal dyad and in the relation between Lia and her parents is preserved. „Sometimes, my mum forces me to go out! My father's behavior? Maybe it's something cultural. My friends go out drinking in the disco. I don't like it; instead I sit in a circle speaking about peace. I am happy, but sometimes I ask myself if I will have the possibility to do this later?" To avoid family disputes, she auto-regulates her socialization. With her close friends, she talks about this as a constraint.

What does Lia mean by "cultural"? Amin's behavior is due to his position as a "father" and not to the fact that he is Arab or Muslim ${ }^{19}$. Sara's father, Italian and Catholic, behaves similarly (Odasso 2013). Why, in two differently constituted transnational spaces, would two fathers employ similar modalities of transmission?

Although they admit that they are proud of their daughters' education, they tend to pass on "something" that is somehow "hidden" behind stricter discursive rules than the mothers. Amin argues: „I have made a big step forward. Sometimes Lia raises her voice when she speaks to me! I have never dared using this tone with my father!" Remains of a hidden memory emerge. Despite his conflicts with his own father, intergenerational respect is still essential for Amin. By doing reflexive work on her family history, Lia understands that her father's "dead memory" (Fogel 2007, p. 515) is re-activated, often unconsciously, in communicating with her: „I can understand him. His father was a boss during his adolescence. It's not easy to change a "bad habit" when it seems normal to you". Amin's past memory, elaborated in the passages and transitions he went through becomes a "live memory" through generational work. Observing Lia's sensitivity, Anna is confident about her daughter's future; instead, she is more worried about her younger daughters who have a different character. Family transmission can take different forms among siblings, as it results from a negotiation between personal characteristics and details of the family history (Favart 2006, p. 84). As stated in the introduction, the involved actors' subjectivity contributes to the success, failure or transformation of what is handed down.

As all adolescents, outside the family Lia and Sara experience norms and values that modify what their parents transmitted by imposing a "restructuration" (Berger/Luckmann 1969). Their socialization as adolescents is different from their primary one and shapes new possible spaces of experience in their lives. 


\section{Kin and non-kin gendered relations}

The choice of peer groups and gender relations outside the family as well as sexuality are representative of the tensions in the family's model of transmission. Daughter-mother and daughter-father interactions perform differently and produce different results. What do the parents think these relations should be like? How do the daughters cope with this?

Anna is aware of her daughter's renouncements: „She can't have a boyfriend until she finishes university! How will she choose the university? Will she stay with the first guy she will meet? Her life will then become trivial one day!" Her father avoids the confrontation by changing the conversation's direction: „I can't sleep when I know that she is still outside".

Trust and control are recurrent terms in the description of Lia and her father's relationship. She knows what she is allowed to do. Nevertheless, she searches for unfolding her own desire among the standard way of life of Treviso's society and the extended family's norms, as both grandmothers live nearby (Claes 2003). This struggle between individuality and community ${ }^{20}$ is very present in the adolescents' reflections. The predominance of the group versus individuality is still significant in some Italian and Moroccan families.

In this phase of Lia's life, romantic relationships are a subject of her friends' debates. But she affirms, „I avoid these relationships. Boyfriends are taboo! I should have a clandestine story”. Her parents think differently. Lia's mother prefers mediation to open conflict: „Things are not so terrible! I have never had to hide what Lia does from him!' But in reality, as in Sara's case, a contrast in the parental dyad is not a suitable strategy to preserve the family unity. Anna, having developed a wider point of view thanks to her "migration of contact" (Odasso 2013, $2015)^{21}$, balances her husband's discourses and practices and her daughter's wellbeing. Amin intends to prevent Lia from repeating the errors that Anna and he committed in their youth. Anna's pregnancy modified the couple's life. „Lia doesn't see my efforts and she treats me as someone from here 22 !" Amin evokes how he reflected the transmission he received and his socialization in Morocco after having migrated to Italy.

Norms change according to time and space. On the basis of their experience, migrant parents act to prevent their children's stigmatization. But they often can do little about it. Structural objective conditions change and the stigmatization's modalities too, as stigmas (Goffman 1963) belong to the society's "common sense".

In Sara's case, the open-mindedness of the contemporary German cultural model contrast with limitations and taboos on sexuality: „Italian friends do this ${ }^{23}$ behind parents' back. They kiss the boys in cars; instead here, I do it freely!" Sara and her mother talk about sex, but secrets remain (Smetana et al. 2006). Her father's opinion is very important for her, especially regarding her choice of a partner. Sara has integrated some family norms. Like Lia, she has developed a selfregulating behavior: „The first time I met him, I made it clear: "if my parents don't accept you, if my father says no, I'll leave you soon". Her father's acceptance is fundamental for her to continue her relationship with a Muslim Turkish boy. „I was afraid to introduce my boyfriend to my father, how would he react?"

Media and socio-political discourses on the Turkish community in Germany affect the perception at a micro-level, distorting individuals' uniqueness. This process reproduces the stigmatization that Italians experienced years before, as al- 
ready seen in Anna's family. But Italians have seldom re-elaborated their past of worldwide massive migration in a reflexive way ${ }^{24}$. Worldwide the memory of migration is a cross-cultural element primordial in a family's "generational work".

Narrations of her parents and grandparents migrant experiences, as well as her own personal experiences, have contributed to Sara's representations on Italy and Germany. The "listened/seen/felt" transmission raises controversies in how Sara defines her Italo-German identity shaped by the "mixed space" made up by the several worlds that she experiences at home and outside. Furthermore, there is "Italy" and "the South of Italy", „the place where the respect for people still exists, it is nice to be together within the family", where there is mutual support. But at the same time Italy is also „a country where parents are too protective and sex before marriage is not lived freely". Italians - this she seems to observe from a particular external point of view - are „people open in their heart but not openminded”. For instance, Sara's relatives expressed prejudicial commentaries when she told them about her relationship with a Turkish boy - „Turkish? You're crazy! What do you want with a Turk?" These words produce emotional and worried reactions in Sara who, somehow, is influenced by this discursive form of control. Even if she shows indifference underling her emancipation in her autonomous choices as compared to her same-age Italian friends, her positioning is not easy. Ida seems ashamed to be part of her daughter's strategy to fight this family taboo: „I told her that she was too young, sixteen years old!" Nevertheless she went to the gynecologist with Sara to take the birth control pill and hide her daughter's first dates with boyfriends from the father. Avoiding to reproduce her own strict mother's example, Sara's mother Ida has tried not to impose restrictions on her daughter: „I could have brought up my daughter strictly as my mother brought me up. But I would have lost her sooner! (...) my daughter has never lied to me, 'cause she has been brought up differently! I had to lie to my mum and my mum lied to my dad". With some arguments, Sara was allowed to bring her Turkish boyfriend home. It was easier for Ida to accept the origin of her daughter's boyfriend when she found out that he was born in Austria, because according to her this could reduce the cultural gap.

Sara thinks about marriage as a central step in her future, even if her vision is different from the one of her mother. She wants ,first cohabitation, 'cause it's better to see what it means to live together; and then if he is the right man, I will marry freely at the town hall". Her mother and her grandmother on the other hand dream that she will marry at church: „it's nice with music, flowers, and people waiting outside; isn't it".

An analysis through the lens of partner choice and sexuality allows us to observe how biographical experiences and context of residence, more than strictly migration, drive especially mothers to revise, at least parts of, the contents of transmissions.

\section{A path towards double loyalty}

A number of other topics (e.g.: langue and religious practices) emerged in the life stories revealing the importance of belonging in the resolution of the conflicts between transmission and socialization. Because of Sara's difficulties at school, Ida 
has always spoken German at home to facilitate her daughter's integration, to the point that Sara told us: „I don't go out with Italians. When I was sixteen years old my Mum said: "we were not born here, but you were born here. I don't want to give you that Italian culture 'cause you have to integrate? Your language has to be German". Sara felt judged for her Neapolitan origins and for her difficulty in speaking Italian correctly while she was attending an Italian school. Thus, she switched to a German school, where she achieved a professional bachelor in retail trade $^{25}$. Sara still speaks Italian with a strong Neapolitan ${ }^{26}$ accent using idiomatic expressions, but when she speaks with or about Ida, however, she prefers to use German, language emotionally associated to the transmission she received from her mother.

Sara's relations to Italy and Germany have been strongly influenced by her father. Gianni has passed on the importance of being able to "adjust" to new surroundings and "to be like a German" (Inowlocki 2000), as he has done: "I have been in Germany for many years; I have a daughter who is here. We have to adapt to Germans". He prevented her from frequenting Italian relatives and friends in Germany, but also discouraged her project of going to work in Italy ${ }^{27}$. Her father wanted to prevent her from re-experiencing the limitations that Italian culture had imposed on him. Once, Gianni told her: „I have to deal with you as a German girl? So, you have to know, when I was with Italians (...) you couldn't have the same life as you have today. Those Italians speak!" Sara met Italian relatives and friends during her short stays in Italy for holidays. In comparison, Germany is the environment in which Sara feels freer to express her personality without fear of being criticized: "Here, you can say what you want and you think, no one looks at you... Germans say directly what they think!" This is the country where she "feels at home", even if some obscure points emerge when comparing the German spaces where she has been socialized, with her enlarged family: "In Germany people are cold, heartless. They are able to close the door in front of someone who needs something". But, at the same time, when in Italy, she does not feel considered as an "Italian" by Italians as she was born and has grown up in Germany - "Even if I say: 'look at my Italian passport! I have Italian parents!'”. In Germany, she is not considered fully German because she is a migrants' daughter. "Your face seems German, but your temperament not at all. You aren't German!"

There is a contradiction between her parents' will to encourage her integration in Germany and her refusal to acquire German citizenship. Sara, like her mother, has not acquired German citizenship. She has Italian citizenship and probably due to her parents' emigration ${ }^{28}$ she experiences a split between juridical and "emotional belonging" (Unterreiner 2015). These difficulties in her belonging have brought her to choose a third community of reference in her own private life: she has recently married her Turkish boyfriend in a civil marriage.

In Veneto, the history of Lia's parents leads her to reveal: "you put together two things and I am the result". Her parents have struggled to match their "worlds", sharing all the steps of their couple's joint migration and awareness with her: "since I was a child they took me to the interreligious association meetings that helped them to speak with others about their difficulties". The parents' choices result in Lia's everyday confrontation with her double origins but "I'm not afraid to be what I am even if sometimes it is hard!"

The regional context, in fact, is even more racist than when Amin arrived. The situation has probably been exacerbated by the economic crisis. Life with a parent or husband who is always considered a migrant - even if he has Italian citizen- 
ship - triggers everyday small struggles in and outside the family, as Anna, Amin and Lia confirm through the narration of their experiences of racism. After the events of $11^{\text {th }}$ September, in 2001, Amin asked for Italian citizenship, keeping his Moroccan citizenship that he also passed on to his daughters ${ }^{29}$. Is double citizenship the mirror of emotional belongings, as a comprehensive dimension of citizenship?

Lia has "experienced" Morocco thanks to her father's and her relatives' narrations, her travels there with family and by herself and the daily presence of her Moroccan enlarged family in her village in Italy since 1990. Some months before our meeting, she had accompanied a friend to Morocco and expressed her concern to pass on the real image of the „Moroccan way of life” instead of seeing it only as a tourist destination. This loyalty for Morocco puts her own history in the continuity of her family trajectory. At school, some classmates emphasize her "otherness" due to her parents' origins and her desire to „hang around only with certain groups, not going to bars and discos like others". According to Lia's narrative, these same acquaintances assert that „they don't like Moroccans, but they say I am not like the other Moroccans". Lia has discussed this at home. Her father has taught her that ,it is important to confront others!” The efforts to set up a dialogue are part of her parents' strategies and subjective resources that they have passed on to her to fight stigmatization or indifference.

Amin has encouraged her to learn about the Moroccan and Arab world, for example through watching news from the Arab world during the "Arab Spring", a topic that Lia has chosen to work on in her master's thesis, and by transmitting a sense of pride about her origin. And beyond all conflicts, Lia shares certain experiences with her father, for instance by fasting during Ramadan, even though she has grown up as Christian: ,it's complicated enough to be the daughter of a migrant! It's crazy but it is my father who encourages me to go to church!" Without imposing his religion or other practices on her, Amin feels the need to educate Lia in a certain way because „she has Moroccan culture. Maybe it isn't perceivable from the outside but in some of her behavior at home it is evident".

Amin and Anna wish for her to establish her own family after she will have completed her studies and after she will have gathered travel experiences, for example through a work camp in Palestine. Curiously, even if Lia criticizes their strategies of transmission, she has the same desires for her future than her parents have for her: „I'd absolutely like to have a family and a lot of children! But for the moment, it's better to travel! I am defining my future in a concrete way... being trustworthy and responsible, giving back the trust that people have given me, being always myself!”

For now, Lia is attending a program on International Relations at the faculty of Political Science in Padua.

\section{Double loyalties as a form of "becoming"}

Transmission is not a linear process (Smetana et al. 2006), especially for those family members that have experienced migration in their biographical trajectories and, thus, have recreated a new notion of self. In these families, women - mothers and wives - constantly act to maintain the family unit while providing their daughters' 
independence. The intimate female alliance generates complicity and semiidentification between daughters and mothers who try to mediate between fathers and daughters, for instance on topics such as romantic relations and sexuality.

Conversely, at first glance, men - fathers and husbands - seem mainly oriented towards control. This is more discursive than concrete. Even if the father's word has a decisive role for the daughters' choices, a deeper analysis helps to understand that strategies of transmission are the results of men's previous experiences and internalized educative models. Furthermore, the purpose of protecting their daughters' honor intertwines with the wish for a successful future for them. What is handed down is the best possibility that fathers found to resolve their own constraints.

Similar to the mothers, fathers also try to prevent their daughters from suffering the stigmatization they have been through themselves, however by using different modalities. Considering non-kin gender relations, the meaning given to "honor" varies between mothers and fathers. Fathers have not directly experienced the pressure of "honor", instead, mothers have already learned to deal with it during their own adolescence. During their passage from adolescence to adulthood, mothers have already contested gendered family transmissions (such as Ida's mother strict education and Anna's family refusal of her partner's choice) and they attempt to change transmissions' contents and modalities. The parental dyad's differential experiences of transmission and socialization have to be considered in the analysis, as intergenerational biographical studies suggest.

Tensions and conflicts can even become resources. The daughters are searching for a balance across transmitted values, their parents' wishes and societal norms. They criticize but never completely reject family resources. The respect for the sacrifices of the parents plays a significant role. Thus, what we have called a "double loyalty" is the consequence of each family member's reflexivity towards coherent family generational work. Each individual, in fact, is "the product of the history, the object of concrete conditions of existence and the producer of this history, seeking to become the subject of his own history; challenges and fragilities in transmission show the relative power of individuals: each one has to confront oneself with a duty of recognition towards the others" (Favart 2006, p. 88).

There is a sense of imbalance linked to the choice of living in a national context that belongs to only one of the two partners, in Lia's family, and to none of them in Sara's family. But a broadened notion of migration, encompassing not only movement across geographic spaces but also subjective change - such as "migration of contact" - entails some socio-ecological transitions that may affect individuals' development and vice-versa.

The conjugal dyad in Sara's family reveals a strong loyalty to Italy while demonstrating that they are able to live 'like Germans'. In Lia's family, this loyalty is the result of a process of awareness undertaken by the father, but also by the mother through her choice of marriage. These are not a misleading processes for the daughters who are born and grew up in the country where their family settled, but they are emotionally "in-between" (Bhabha 1994, p. 4/173) different geographical transnational spaces. Sara and Lia do not adhere to all kin values proposed; on the contrary, criticizing them and playing with the values proposed outside their family they re-invent their own social position. Neither migrants nor fully nationals, they are able to recreate new structures of plausibility with regard to kin and non-kin norms and values. In the discontinuity of transmission a form of the new generations' double loyalty appears. 


\section{Conclusions}

Multiple national and social references, attempts to balance old and new norms, kin and non-kin gender relationships represent good entrance points to observe transmission and socialization.

Migration influences generations differently due to the contrasting experiences of lived or suffered migration. Concretely, it is the meaning given to the intimate passages of each parents' migration process - both spatial-geographical migration and the migration of contact - that plays a core role in transmission modalities. When migration has deeply impinged on parental cohesion, some analogies in the children's positioning emerge both in migrant and in mixed families. The awareness of the family history and parents' experiences awaken a new consciousness of their roots among the younger generations, creating a "double loyalty" to the parents' content of transmissions that can be adapted to the new norms acquired from other referents. This negotiation of transmission and socialization contents contributes to the young generations' challenges to make their own way in the society they were born in.

Choosing two families that share a common Italian element, while presenting different pattern of migration and living in different national contexts, we discovered that family structure and structural contexts do not play a core role in passing on and in adolescents' positioning.

In their path to adulthood, the youths have to integrate coherently the pieces of biographical information into their own personal history. This often happens during adolescence when breaks in the interrelation between intimate family values and public socio-environmental ones tend to be shrouded in ambiguity due to somehow conflicting referents and the loss of the certitude of childhood. This phase might be depicted as a process in itself between the dynamic interactive processes of socialization and transmission. Adolescence is a space of reconstruction and norms' balance which results in new forms of emotional and "denationalized" (Sassen 2002, p. 286) belonging.

A denationalized perspective allows not only to read the process of "becoming women" in the frame of the "nation" from a historical and legal point of view (that is, of migration as movement across borders, residence, citizenship), but also to add some features that nuance the notion of belonging as it appears in alternative solutions of "becoming", such as the double loyalty, an emotional affiliation to a family model, to certain practices, to territories). Hence, observing in practice the individual's subjective and discursive feeling of belonging, we propose a comprehensive and creative notion of belonging that fits migrants' children, binational families' children and individuals at large. The daughters studied in these microcases are a positive metaphor of the denationalization that we witness at the macro-level nowadays. Concretely, migration is not limited to geographical movements, but to an intimate status common to many individuals worldwide.

Lia and Sara, as all (also migrant or semi-migrant) daughters, have to conciliate discordant cultural, social and intergenerational values to develop their biographical space to become women creating a new set of transmissible information that they will hand down eventually themselves. Migration becomes not only a lived experience but a state of mind that is possible to pass on. 


\section{Notes}

1 Along generations, an operation of selection of what has to be remembered and passed on allows to safeguard the "family myth" (Neuberger 2011, p. 32). This myth perpetrates family identity and it may reinforce personal identity through generations. Thus, transmission derives from searching for an equilibrium between mandates of conservation and imperatives of change (Mannheim 1929/1976).

2 These passages vary considerably according to the initial migratory project, the historical period, and of course social class, age, sex and nationality (Apitzsch 2009). See also Ribbens McCarthy et al. 2013, p. 200.

3 This method was invented to observe transmission over generations (Bertaux 1997; Bertaux/Bertaux-Wiame 1988).

4 Ursula Apitzsch applied to migration Urie Bronfenbrenner's psychological theory of the "ecology of human development" (Bronfenbrenner 1977, p. 514). This is the progressive individuals' accommodation to the changing environment, or systems such as family settings, peer group, larger social environment, institutions and ideologies, in which they are involved during their lives. These systems are defined as micro-, meso-, exo- and macro-systems in Bronfenbrenner's terminology.

5 In a binational marriage, the partners have different nationalities. When the non-national partner has acquired the nationality of the other, the marriage may be still considered as "mixed". A mixed marriage breaks real and/or symbolic boundaries (e.g.: religious affiliation, national belonging, culture, social class, etc.), thereby provoking positive and also negative reactions in the social environment. See Odasso (2014) and Varro (2003).

6 Between 1955 and 1960, foreigner guest-workers, named Gastarbeiter, were recruited to support German economic reconstruction (Gabaccia 2000). The history of Sara's family was collected by M. Gigliotti for her $\mathrm{PhD}$ dissertation on the experiences of three generations of Italian women who migrated, were born or grew up in Germany since 1955, the year of the agreement between Italy and Germany for workforce recruitment.

7 The notions of "family success" and "social mobility" are linked to quantitative empirical methods. These data have to be integrated by subjective indicators, such as the interviewee's appreciation of his/her position compared to the one of his/her parents and children (Attias-Donfut 2001, pp. 954-955).

8 The original German expression is dialektische Familienorientierung (Apitzsch 1990).

9 Sara opposes her mother's position and stresses her own emancipation by explaining that she ended a relationship with a boy from Calabria in Southern Italy because she found him too jealous and possessive.

10 Italians were named "Spaghettifresser" (overeaters of spaghetti), "Katzelmacher" (spoon producers), or "Ithaker" (globetrotter without a homeland).

11 They are respectively seven and five years old. The daughters' names follow a change of awareness in family choices over time. Different from Lia, her younger sisters have Arab names.

12 Moroccans arrived in Italy after the closure of French borders (1974). Once in Italy with a tourist visa, Amin rapidly obtained a work permit thanks to the migrant law $n$. 39 of 1990

13 They had been migrants to Canada, where Anna was born. Her parents went back to Italy when she was three years old.

14 Lia's family history was collected by L. Odasso for her Ph.D dissertation on a comparative study on the influences of everyday and institutional racism on intermarriages in Alsace (France) and in Veneto (Italy). The sample consists of families with one parent who defines him- or herself as "Arab" (Odasso 2013). Starting from the juridical dimension - bi-national couples at the time of marriage - and other symbolic dimensions, such as religious affiliation and ethnicity the analysis shows how "mixedness" is still determined by the outside context and stigmatization affects not only the migrant but also the native partner. 
15 Party founded by U. Bossi in 1991. Its electoral scores expanded over the 1980s.

16 To quote the well known speech of the mayor of Treviso: "Our civilization is superior to the one of people coming from the desert, we do not want a kasbah in Treviso and migrants ruin the "Piave race". Piave is the main river of the Veneto region and 'Piave race' is a racist metaphorical expression to define Veneto natives (Trocino 2002). It is not by coincidence that during this period Amin applied for Italian citizenship to secure his position.

17 Amin thinks that his father ruined his career as a football player in the Moroccan first division team: "At one point I said to myself 'Stop! I really want to live my life!"

18 Anna and Amin met in a local group of the Caritas and they are members of an association of inter-religious couples.

19 Reported stereotypes on Arabs recur in Amin's narration (e.g.: ,in the village, the inhabitants thought that I wanted a lot of children: this idea that an Arab wants a son, the male.")

20 Here, the term means group at large without any ethnic meaning.

21 The choice to marry a foreigner affects the native partner. In this way intermarriage may be conceptualized as a "joint migration", to include the efforts that the native partner continuously makes to get closer to her (spatial) migrant partner's experience (e.g.: by sharing and experiencing juridical restrictions). See the psychological approach to this notion in Gozzoli/Regalia (1995, p. 153).

22 Here, Amin means someone who has grown up in Italy.

23 Sara is talking about having sex.

24 Venetia and Campania are Italian regions with a high rate of emigrants. Italians migrated mainly to the United States (more than 5 million), to France and to Switzerland (more than 4 million Italians to each), to Argentina (3 million), to Germany (2, 5 million) and to Brazil (1, 5 million), as well as to Africa and Australia (Gabaccia 2000, pp. XVII-XVIII).

25 In Germany, at home, Italian children were used to speak a dialect and not standard Italian. This led to conflicts with teachers at school, and Sara asked her father for permission to leave the Italian school.

26 Neapolitan is the dialect from the region of origin of Sara's parents

27 Sara wanted to work in a hotel in southern Italy.

28 In order to pass on their Italian citizenship, the descendants of Italian migrants must have never refused their Italian citizenship in the past (law n. 91 of 1992).

29 In Italy, children of at least one Italian parent have Italian citizenship. Double citizenship is permitted since 1992 (law n. 91). In Morocco, the children of a Moroccan man are Moroccan and, since 2007, children of a Moroccan woman too. Foreign partners who want to acquire Moroccan citizenship have to attest a five years' residency in the country. The decision from the Ministry of Justice follows the King's decree.

\section{Bibliography}

Attias-Donfut, C./Wolff, F. C. (2001): La dimension subjective de la mobilité sociale. In: Population 56(6), pp. 919-958.

Apitzsch, U. (2009): Transnationales biographisches Wissen, Gender Mobil. Münster.

Apitzsch, U. (1990): Migration und Biographie. Zur Konstitution des Interkulturellen in den Bildungsgängen junger Erwachsener der 2. Migrantengeneration. Habilitationsschrift, Bremen.

Berger P./Luckmann T. (1969): La realtà come costruzione sociale. Bologna.

Bertaux, D. (1997): Les récits de vie. Perspectives ethnosociologique. Paris.

Bertaux, D./Bertaux-Wiame, I. (1988): Le patrimoine et sa lignée: transmissions et mobilité sociale sur cinq générations. In: Families and Careers in History, Life Stories/Récits de vie 4, pp. 8-25. 
Bertaux, D./Delcroix, C. (2009): Transmissions familiales et mobilités. In: Migrations \& Société 21(123-124), pp. 89-96.

Bhabha, H. (1994): The Location of Culture. London.

Bourdieu, P. (1994): Raisons pratiques. Sur la théorie de l'action. Paris.

Burawoy, M. (1998): The Extended Case Method. In: Sociological Theory 6(1), pp. 1-28.

Bronfenbrenner, U. (1977): Toward an Experimental Ecology of Human Development. In: American Psychologist 32(7), pp. 515-531.

Claes, M. (2003): L'univers social des adolescents. Montréal.

Delcroix, C. (2013): Ombres et lumières de la famille Nour, Paris.

Delcroix, C. (1995): Des récits de vie croisés aux histoires de famille. In: Current Sociology 43(2-3), pp. 61-69.

Elias, N. (1991): La société des individus. Paris.

Essed, P. (1991): Understanding Everyday Racism. An Interdisciplinary theory. New York.

Favart, É. (2006): La transmission familiale s'approprier le passé familial entre frères et sœurs. In: Pensée Plurielle 1(11), pp. 83--89.

Fogel, F. (2007): Mémoires mortes ou vives. Transmission de la parenté chez les migrants. In: Ethnologie française 37(3), pp. 509-516.

Gabaccia, D. (2000): Italy's Many Diasporas: Elites, Exiles and Workers of the World. New York.

Glaser, B./Strauss, A. (1971/2010): Status Passage. New Brunswick/London.

Goffman, E. (1963): Notes on the Management of Spoiled Identity. Upper Saddle River.

Gozzoli, C./Regalia, C. (1995): Migrazioni e famiglie. Percorsi, legami e interventi psicosociali. Bologna.

Inowlocki, L./Lutz, H. (2000): Hard Labor. The "Biographical Work" of a Turkish Migrant Woman in Germany. Women in Transit Between Tradition and Transformation. In European Journal of Women's Studies 7(3), pp. 301-319.

Inowlocki, L. (2000): Doing "Being Jewish": Constitution of "Normality" in Families of Jewish Displaced Persons in Germany. In: Breckener, R./Kalenkin-Fishman, D./ Miethe, I. (eds.): Biographies and the division of Europe: Experience, Action, and Change on the "Eastern side".Opladen, pp. 159-178.

Inowlocki, L. (1993): Grandmothers, Mothers, and Daughters. Intergenerational Transmission in Displaced Families in Three Jewish Communities. In: Bertaux, D./Thompson, P. (eds.): Between Generations. Family Models, Myths, and Memories. Oxford, pp. 139-159.

Mannheim, K. (1929/1976): Sociologia della conoscenza. Bari.

Negrini, A. (2001): Uomini e frontiere. Problemi socio-economici dell'emigrazione italiana in Germania. Roma.

Neuburger, R. (1995/2011): Le mythe familial. Paris.

Odasso, L. (2014): Mariage mixte. In: Pfefferkorn R./Bihr, A. (eds.): Dictionnaire des inégalités. Paris, pp. 238-240.

Odasso, L. (2013): Les chemins de la mixité conjugale. In: Migrations et Société (147-148), pp. 11-31.

Pinquart, M/Silbereisen, R. K.(2004): Transmission of values from adolescents to their parents: the role of value content and authoritative parenting. In: Adolescence 39(153), pp. 83-100.

Ribbens McCarthy, J./Gillies V./Hooper C. (2013): Family troubles? Exploring changes and challenges in the family lives of children and young people. Bristol.

Sayad, A. (1994): Qu'est-ce que l'intégration ? In Hommes \& Migrations, N. 1182, p. 8-14.

Sassen, S. (2002): Towards Post-National and Denationalized Citizenship. In: Isin, E./Turner, B. (eds.): Handbook of Citizenship Studies, pp. 277-291.

Schütze, F. (1987): Symbolischer Interaktionismus. In: Ammon, U. (ed.): Soziolinguistik. Ein internationales Handbuch zur Wissenschaft von Sprache und Gesellschaft. Berlin/New York, pp. 520-553. 
Smetana, J. G./Metzger, A/Gettman, D. C./Campione-Barr, N. (2006), Disclosure and secrecy in adolescent-parent relationships. In: Childrend Development 77(1), pp. 201-17.

Trocino, A. (2002): Il Vescovo abbraccia gli immigrati. Il Sindaco: li caccerò. In: Il Corriere della Sera, p. 5.

Unterreiner, A. (2015): Enfants de couples mixtes. Liens sociaux et identités. Rennes.

Varro, G. (2003): Sociologie de la mixité. De la mixité amoureuse aux mixités sociales. Paris.

Varro, G. (1992): Discours sur les prénoms et les sentiments identitaires. In: Tradisis 1(0), pp. 27-51.

Wall, K/Gouveia, R. (2014): Changing meanings of family in Personal Relationships. In: Current Sociology 62(62), pp. 352-373. 